\title{
SCANNING FOR BEVARING
}

\author{
Snorre Normann Bache
}

Nidaros Domkirkes Restaureringsarbeider har siden 1869 drevet en kontinuerlig og nitidig restaureringsprosess av Nidarosdomen, nasjonalhelligdommen vår. I 1969, hundre år etter at arbeidet ble påbegynt, var selve gjenoppbyggingen av katedralen, som tidligere delvis lå i ruiner, fullført. Mange av figurene som i dag danner den omfattende utsmykkingen av katedralen ble under gjenreisningen gjenfunnet som fyllmateriale $i$ forstøtningsmurer. Figurene ble kopiert ved hjelp av gipsavstøpninger, rekonstruert og hugget $i$ stein. Ca 4000 avstopninger ble gjort, slik at man kunne sette på plass originalene, samtidig som man hadde lagret en gipskopi som dokumentasjon. I 1983 brant Erkebispegärden, og med den samtlige gipsavstopninger. En mengde arbeid og uvurdelig dokumentasjon gikk tapt i flammene.

\section{Dagens Situasjon}

I dag skriver vi år 2004 på kalenderen. Mange av figurene som smykker Nidarosdomen er i ferd med å lide forvitringsdøden. Århundrer med klimatisk slitasje og erosjon begynner å sette sine spor. Enkelte figurer griner groteskt uten ansikt. Noe må gjøres for å dokumentere denne kulturskatten. Ved restaureringsarbeidenes steinhuggerverksted hugger man kopier av de mest utsatte figurene. Disse erstatter originalskulpturen, som i sin tur kan oppbevares innendørs i museet.

Enkelte av figurene er blitt så oppløst i overflaten at man ikke lenger kan lage avstøp av dem; til det er de blitt for skjøre. For enkelte figurer er en hver berøring forbundet med risiko for at klebersteinen løser seg opp til sand.

\section{NytenkNing}

Trondheimsfirmaet VINN Design har i samarbeid med Nidarosdomens Restaureringsarbeider gjort et stykke pionerarbeid med skånsom dokumentasjon og reproduksjon av fornminner. Med firmaets utstyr og kompetanse kan de digitalisere figurer og skulpturer slik at man får gjenskapt figurene i tredimensjonale datamodeller med bedre enn en tiendedels millimeters nøyaktighet. Datafilene er dokumentasjon bedre enn noen fysisk, manuell oppmåling. Man kan bygge opp en digital database med dokumentasjon av figurers geometri.

Ved fremtidig behov for dokumentasjon kan man "skrive ut", dvs fysisk reprodusere datafilen som gjengir en gitt figur i en tredimensjonal "skriver", slik at man får en 3-dimensjonal 



Fig. 1.

Fig. 2.

plastmodell i naturlig størrelse. Denne plastmodellen kan så være mal for f. eks. steinhuggeren som skal hugge en kopi av en skadet figur.

\section{PRINSIPP}

Digitaliseringen (3d-scanningen) av figurene gjøres ved hjelp av en 3-dimensjonal lysrasterscanner. Denne består av en kraftig lyskilde som projiserer et raster (linjemønster) på objektet, samt to høyoppløselige digitalkameraer. Kameraene registrerer lysrasteret som todimensjonale punkter (Fig. 1-2).

Et lysraster projisert på et objekts overflate vil bøyes av som følge av objektets kurvatur. Her ses bilder fra scanningen av et gammelt gipsavstøp av "Fidla" (Felespilleren), tilhørende Nidaros Domkirkes Restaureringsverksted (NDR). Den todimensjonale avlesningen av denne avbøyningen danner sammen med komplekse matematiske iterasjoner av fysiske formler utført i en kraftig datamaskin grunnlaget for omsettingen av punkter i planet til romlige punkter. Man må som ved konvensjonell fotografering ta flere bilder for å "sy sammen" delbildene til en helhet, da man ikke klarer fange inn mer enn én side av objektet ad gangen. Programvaren vil ved scanning plassere de 3-dimensjonale lappene hvert bilde gir riktig i forhold til hverandre (Fig. 3, 4 og 5).

Fig. 3-5.
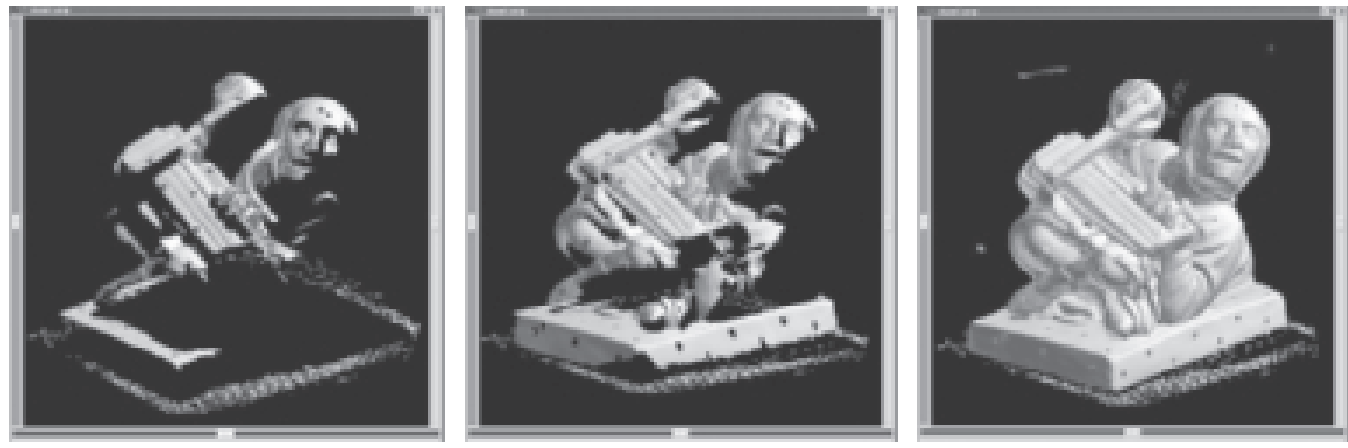
Figuren er nå dokumentert, og dokumentasjonen kan lagres i database. Idet man ønsker en fysisk kopimodell henter man datafilen ut fra basen. Filen kan da skrives ut i tredimensjonal skriver, eller brukes som grunnlag for fresing i tre eller metall.

\section{BYGGING I TREDIMENSJONAL SKRIVER}

3d-skriveren er en såkalt stereolitografimaskin, til daglig betegnet som SLA. Med denne kan man "skrive ut" tredimensjonale figurer ved å bygge opp tynne lag av materiale. Den tredimensjonale datamodellen av den scannede figuren snittes $\mathrm{i}$ en spesiell programvare opp i tynne skiver på 0,075 mm langs én akse. Etter delingen vil da figuren bestå av et utall snitt. Randkurvene representert i snittene danner da styringsbanen for en laserstråle som "tegner av" snittene på overflaten av flytende fotosensitiv resin (epoxy) i en tank (Fig. 6). Der laserstrålen har sveipet, herder resinen umiddelbart til fast materiale. Ved oppstart ligger en nedsenkbar plattform rett under resinoverflaten, slik at det første materialet herder direkte på platen. I det neste snitt skal "avtegnes" i resinen, senkes plattformen $0,075 \mathrm{~mm}$ ned, slik at det gående. Idet alle snittene er avtegnet har man en ferdigbygget modell.

Prosessen er nå fullført, og SLA-kopien kan leveres til steinhuggerverkstedet for kopihugging Fig. 7).

Scanningen av "Fidla" ble gjort innendørs på VINN Designs Scanningslaboratorium. Utstyret kan imidlertid også benyttes ute i felten.

Fig. 6. Prinsipp SLA-maskin



Fig. 7. Original, digital modell etter én dag og til slutt ferdig kopi etter totalt fire dager




100 SCANNING AV SKULPTUR

\section{PÅ NidAROSDOMEN}

I september 2003 gjorde firmaet en jobb for NDR ute i felten. En middelalderfigur med mangelfull dokumentasjon var objektet. Denne figuren (Fig. 8), som antas å forestille kong Sverre, var på grunn av forvitring blitt fragmentert i overflaten. Ettersom figuren er hugget ut av en stein som er en del av veggkonstruksjonen, lar den seg ikke demontere for dermed og kunne kopieres i steinhugger-verkstedet. Videre er detaljrikdommen ennå også såvidt god at originalen ikke krever utskiftning. Derimot burde geometrien vært dokumentert så snart som mulig. NDRs konservator var svært skeptisk til kovensjonelt avstøp. En gipseller silikonavstøpning kunne fort medføre at den skjøre geometrien gikk i oppløsning ved avtakning av formen. Videre er man i fagkretser begynt å bli kritisk til bruken av avstøp, da

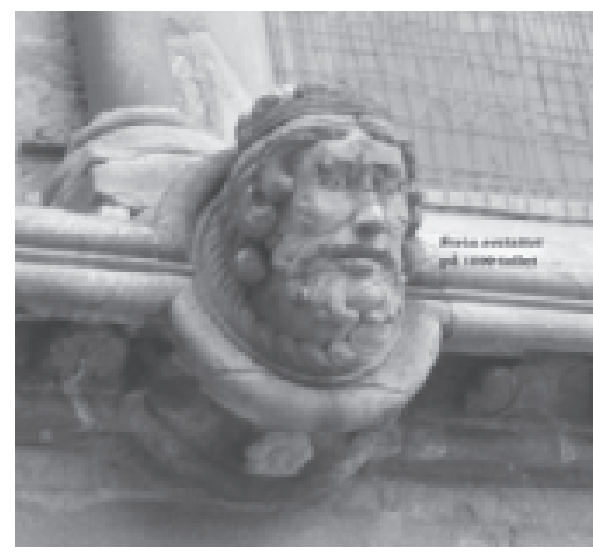

Fig. 8. Portrett man antar kan vere Kong Sverre.

man ikke riktig vet langtidsvirkningen som oppstår etter kontakt mellom stein og gips/silikon. Berøringsfri 3-d scanning ble dermed redningen for dette portrettet.

Steinen var original middelalder med unn-

Fig. 9. Scanning med NDRs konservator Ronald Hübner.

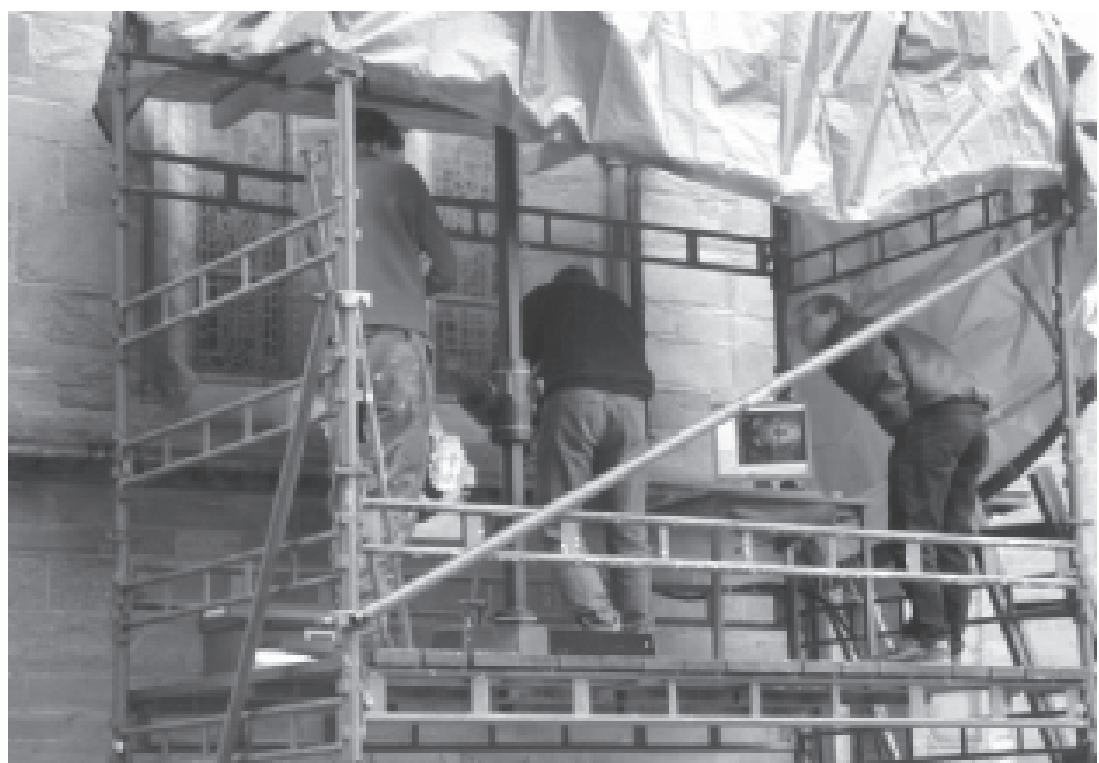


tak av av hakeparti og nese, som mest sannsynlig var erstattet på 1800 tallet. Konservator ved NDR, Ronald Hübner var med under hele prosessen for å se til at alt gikk riktig for seg (fig. 9).

\section{Tidsforbruk}

Portrettet ble digitalisert på en dag, fire dager senere var en kopi i naturlig størrelse bygget i SLA. Denne kan så i fremtiden benyttes som mal for stenhuggerne når de skal hugge en kopi av den litt slitne originalen (Fig. 10, 11 og 12).

\section{Fremtidige prosjekter. Mange SPENNENDE ANVENDELSER...}

Dokumentasjon. Forvitringen av steinfigurene på Nidarosdomen skjer raskt, og vi ser for oss at det vil være verdifullt å få dokumentert så mye som mulig ved hjelp av scanning i løpet av kortest mulig tid. På den måten kan en digital database over figurene, slik de ser ut pr dags dato bygges opp. Om man fra restaureringsverkstedet side ikke har kapasitet eller $ø$ nsker om å reprodusere disse figurene før senere år, så har man iallefall dagens utgangspunkt å gå ut ifra, noe som vil være verdifullt med tanke på forvitringsprosessens. Man kan tenke seg at man printer ut SLA-modeller fra denne databasen etter behov og ressurser.

Forskning. Scannemetoden er svært godt egnet for registrering av geometriske avvik. Det vil si at man scanner en og samme figur med et lengre tidsrom i mellom. I dette tidsrommet vil man potensielt ha en forvitringsprosess som har tæret av figurens geometri. Ved å legge to scan oppå hverandre kan man ved hjelp av en spesiell programvare avlese avviket som et kotekart eller ved hjelp av farvekoder som legges på den digitale geometrien. Ved å scanne en
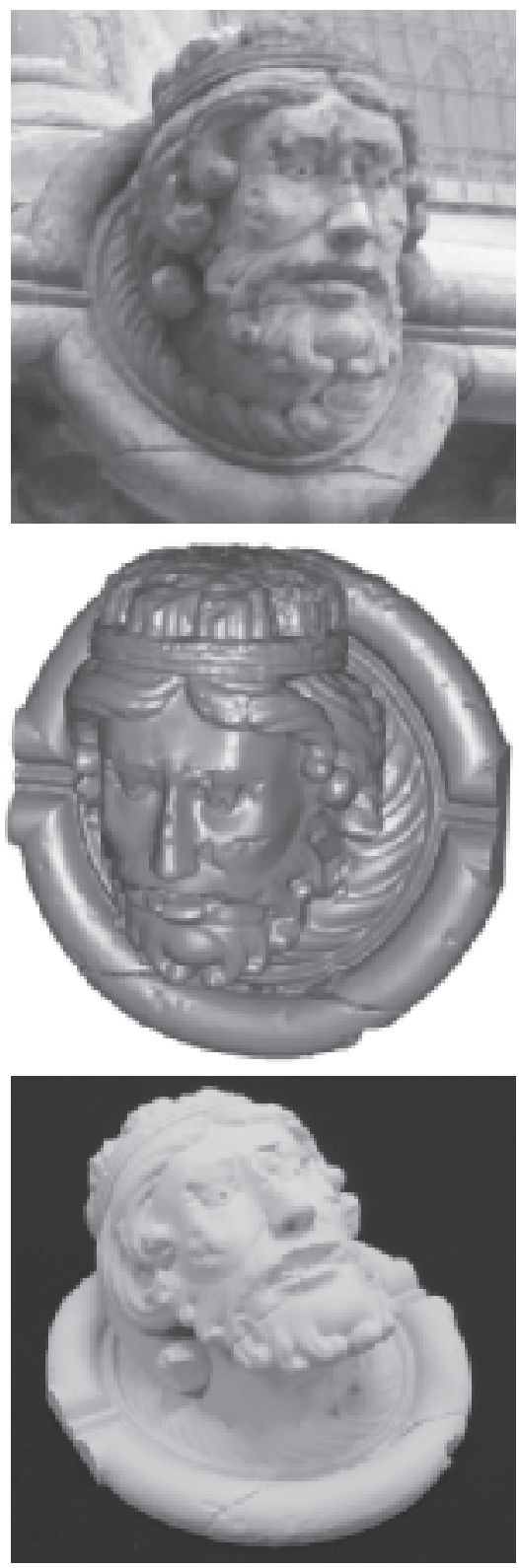

Fig. 10. Portrettet på Nidarosdomen

Fig. 11. Datamodell

Fig. 12. Ferdig SLA-modell fire dager senere 
102 bestemt figur med et visst mellomrom (f.eks 1 år) kan man eksakt overvåke forvitringen $i$ årenes løp, og kontinuerlig rapportere i et lettfattelig oppsett som kan leses og tolkes av personer med ikke-teknisk bakgrunn.

Helleristninger. Frem til dags dato har bevaring av helleristninger bestått i å "tusje opp" risningene med maling for å gjøre de bedre synlige. Prosjektleder for Bergkunst-prosjektet ved Universitetets Kulturhistoriske Museer i Oslo, David Vogt, hevder at malingen fremskynder forvitringen av fjellet. Dagens metode for dokumentering av helleristninger med nattlig lyssetting, kritting, plastlegging og tusjing før avfotografering, er både tidkrevende og noe "grov". Videre gir den kun et todimensjonalt, flatt bilde av ristningene, der dybden mangler. Med scanning kan ristningene med sprekker og tekstur dokumenteres tredimensjonalt, hvorpå filtrering av bergoverflate kan mønsteret til å tre klart frem (Fig. 13).

Farvescan. Som tidligere nevnt er scanning av geometrier med farge på trappene. Dette er en utbygging av dagens system. I tillegg til å

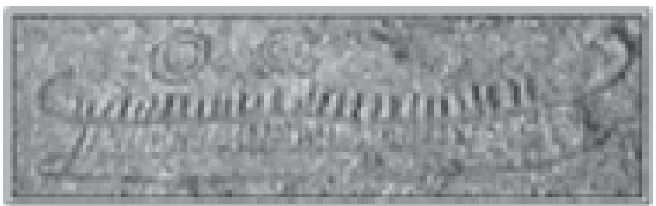

Fig. 13. Helleristning på gården Nag i Ryfylke, datert til ca. 500 f.Kr.

dokumentere 3-dimensjonal geometri vil det utbygde systemet også kunne dokumentere farver, nyanser og tekstur på objekter. Et slikt system åpner mulighetene for utfyllende dokumentasjon av såvel treskulpturer (f.eks. malte madonnafigurer og altertavler i kirker) som treskårne, rosemalte objekter og veggmalerier. $3 \mathrm{~d}$-scanning er et godt bidrag til vern og bevaring av skatter fra fortiden for fremtiden.

\author{
Snorre Normann Bache \\ Prosjektingeniør/civ.ing. \\ E-mail:snorre.bache@vinndesign.no \\ VINN Design AS: www.vinndesign.no
}

